\title{
SPORTS AS A DYNAMIC FORCE IN DEVELOPING RELATIONS IN GLOBAL POLITICS
}

\author{
Prof. Dr. Aslam Pervez Memon* \\ Pro Vice Chancellor, University of Sufism and Modern Sciences, \\ University of Sindh, Jamshoro, Bhit Shah Campus \\ (HEC Recognized Scholar) \\ Ms. Fahmeeda Memon** \\ Lecturer, Department of Political Science, \\ University of Sindh, Jamshoro, Pakistan \\ Prof. Dr. Kiran Sami*** \\ Professor, Department of Political Science \\ University of Sindh, Jamshoro
}

\begin{abstract}
Sports are understood as one of the dynamic forces in developing national integrity among the masses creating national unity in the country; where as sports diplomacy is referred when sport is used as a political means to improve relations and some times may worsen diplomatic relations between two nations. The intention is to bring about fundamental changes relating to fine relations. While the Olympics events are the leading political examples of using sports for diplomatic means, such as cricket, table tennis and football as well as other international sports competitions have also been used in this regard. In the case of Apartheid, competitive sport was used to isolate South Africa that brought major changes in nation's social structure in terms of socio- political relationship, examining the sports diplomacy that adopted by Nelson Mandela of South Africa, and Iran's former President Khatami's inspiring initiative provided an opening for a watchful rapprochement policy with USA, advocating people-to-people contacts between these two nations to release tensions developed between them that may be compared with ping pong diplomacy, which softened US-Chinese relations.
\end{abstract}

\section{Keywords:}

Sports, rapprochement, dynamic, diplomacy, apartheid, relationship, pride, tensions, integrity and nationalism.

\section{Council for Innovative Research}

Peer Review Research Publishing System

Journal: Journal of Social Sciences Research

Vol. 9, No. 3

editor@jssronline.com

www.jssronline.com 


\section{Methodology}

This article has been developed on the basis of descriptive research method. The information was collected from various books, newspapers and magazines, analyzing it from personal interviews of leading former international players of Football, Cricket and Table Tennis players and also from my personal sports experience. The survey questionnaire was administered to respondents for further process and analysis.

\section{Introduction and Discussion}

Most sports are contested between national teams, which encourage the use of sporting events for nationalist purposes; it may have done intentionally or some times it may be with other reason. The national solidarity achieved through sport may be one of the primary sources of developing nationalism, as popular sports events, which people like the most, are considered a matter of national pride; The Ashes is a matter of national pride between England and Australia. Similarly, in cricket India vs. Pakistan match puts both countries on a virtual standstill as it is has become all about national pride during their matches. The Olympic Games are the premier stage for nationalist purposes, as it reflects the history of political conflict since its inception at the end of the 19th century. The 1936 Summer Olympics held in Berlin was an illustration, paramount recognition of the sensitivity of the prevalent situation, where an ideology was rising which used the Olympic event to strengthen its position through propaganda. The United States refused to participate and politically aligned nations joined her in the boycott of summer Olympics of 1988 and the Soviet Union considered it as the part of the Cold War conflict.

\section{Apartheid Policy}

It is notable that sporting boycott of South Africa during Apartheid was understood to have played vital role in forcing South Africa to open up their society and to end a global isolation. South Africa was barred from the 1964 Summer Olympics and many sports' governing bodies expelled or suspended membership of South African affiliations. It was said that the international boycott of apartheid sport has been an effective move toward sensitizing world opinion against apartheid and mobilizing millions of citizens for action against that disgraceful political system. The imposed ban helped change official policies towards participation in sports.

The South African Table Tennis Board (SATTB), founded in contravention to the United Nations human rights, white South African table tennis board was replaced in consequence of the boycott of the International Table Tennis Federation. While former body was able to participate in the world championships held in Stockholm in 1957, and team members were refused passports by the government. It ruled that no black could compete internationally except through the white sports body.

United Nations in 1980 advised member countries to inform about Sports Contacts with South Africa and provide a list of sportsmen who have participated in sports events. That action proved to be an effective instrument to discourage collaboration with apartheid sport and later on in the same year South Africa was also expelled from most international sports bodies. The International Olympic Committee adopted a declaration against "apartheid in sport" on June 21, 1988, for the total isolation of apartheid sport.

\section{Olympics Charm}

In 1936 Olympics, Adolph Hitler used it as a vital occasion to promote superiority of Germany with his ideological belief of racial domination. These games were used as a means of strengthening the German potency and bringing unity among the youth. It was also believed that sport was a "way to weed out the weak, Jewish, and other undesirable communities. As a result, many Jews and Gypsies were banned from participating in sporting events, while Germany secured top position in winning medals, the Nazi portrayed ethnic Africans as inferior nation was dispelled by Jesse Owens' gold medals in the $100 \mathrm{~m}, 200 \mathrm{~m} 4 \times 100 \mathrm{~m}$ relay and long jump events.

Again, in 1968, Olympic Games were used to demonstrate the world the plight of the African-American struggle during the civil rights movement in their home country. The well-known Black Power salute was performed by black American, John Carlos during the medal ceremony in Mexico City. In 1972, Israeli Olympic athletes of Jewish team were massacred in an assault by Palestinian gunmen at the Olympic village that eventually resulted in 17 deaths of the team members. In 1980 the Soviet invasion of Afghanistan led to a boycott of the Moscow Olympics by a large part of the western nations and their allies in protest against Russian actions. In the 1984 Los Angeles Olympics the Soviet Bloc countered a retaliatory action in the form of boycott of the games in response to the American-led Moscow games.

\section{Ping-Pong Diplomacy}

The exchange of table tennis players from the United States and the People's Republic of China led to make softer policies in Sino-American relations that eventually led US President Richard Nixon to endorse rapprochement policy with the Chinese government. It was the first initial public information of improved U.S.-China relations known to the world on April 6, 1971, when the American Ping-Pong team was visiting Japan, received a surprise invitation from their Chinese colleagues to visit People's Republic of China. On April 10, nine players, four officials, and two spouses stepped across a bridge from Hong Kong to the Chinese mainland. It was the first group of Americans allowed in Chinese territory since the Communist takeover in 1949. Ten journalists, including five Americans, were also invited to cover the visit of the team thus, ending the information blockade from the People's Republic took place since 1949. The delighted American public were aware of the daily progress of the visit through newspapers and television, as the Americans played and lost 
exhibition matches with their hosts, traveled around the Great Wall, Summer Palace and during their visit chatted with Chinese students and factory workers and had the opportunity to attended the Canton Ballet.

\section{Cricket Charisma}

The charisma of Cricket has also played important role in developing relations between the nations help to improve and some times severe the relations between them. Pakistan and India is the good example, which seems developed tensions in global politics. Following the Soviet invasion of Afghanistan, and Soviet pressure on India to deflect the tension they are confronted with. Pakistan's President General Zia ul-Haq, in 1987 watched a test match between India and Pakistan in Jaipur, apparently it helped to cool down the tensions. Further, fifteen year break in playing test matches between them, cricket tours between India and Pakistan were also revived in 2004 in the wake of diplomatic initiatives to bury past history of mutual hostility. Both sides relaxed their tough visa regulations for each other, allowing thousands of fans to travel across the border.

Taking the advantage of the cricket diplomacy President General Pervez Musharaf visited India in 2005 apparently for a cricket match. The trip, however, quickly turned over to summit meeting as both sides urged to seize a historic chance to end their dispute over Kashmir and often this enmity has traced with a religious-political twist to it. A Pakistani fan in Karachi ran on the pitch to attack the Indian captain, and fans threw stones at the Indian players during the match in Karachi. In 2000 a Hindus extremist dug up the cricket pitch in New Delhi to protest against Pakistan team's visit. The Mumbai attack on Parliament in 2008 by the terrorists which are believed to be from Pakistan also aggravated the situation and India boycotted all kinds of mutual talks between these bordering nations.

\section{Football Attraction}

The notorious war between El Salvador and Honduras took place largely based on the sensitive rivalry of Football game that build up to the war along with severe socio-economic issues like immigration and land reform were the factors for leading to chaos in these countries. The inflammation of tensions encouraged rioters during the second North American qualifying round for the 1970 FIFA World Cup and disturbances broke out during the first game in Tegucigalpa, but the situation worsen in San Salvador. The Honduran fans were physically beaten and humiliated, its flag was torched and insulted national anthem. Consequently the emotions of both nations became agitated. In retaliation, violence against Salvadoran residents in Honduras increased and number of Salvadorans brutally killed and tens of thousands began fleeing the country. The press of both nations contributed to a growing climate of near-hysteria, and on June 27, 1969, Honduras broke diplomatic relations with El Salvador. On July 14, 1969, the Salvadoran army launched an attack against Honduras. The Organization of American States negotiated a cease-fire which took effect on July 20, with the Salvadoran troops withdrawn in early August, 1969.

In 1986 Mexico World Cup, after the Falklands War between Argentina and the United Kingdom, Diego Mara Dona scored a goal that fuel the fire between the two sides and matter worsen as it was an unrecognized foul using the hand (referee did not watch it) to score a goal that sharpened relationships between these nations. The opponent team and large number of spectators called it as Hand of God.

In 1998 FIFA World Cup held in France, Iran recorded their first World Cup victory in the second game, beating the United States by 2-1 goals for Iran. The match was preheated with much excitement because of each country's political stance after the Iranian revolution. However, in an act of defiance against all forms of hatred or politics in sports, both sides presented one another with gifts and flowers and stood together for a picture before the match kickoff.

The 2004 AFC Asian Cup held in China made headlines due to events that took place during the final between China and Japan, apparently due to historical relations dating back to World War II (Second Sino-Japanese War and Nanjing Massacre) As the Japanese national anthem was being played, the home fans expressed their anti-Japanese sentiment by insulting national anthem with their anti-Japan slogans. The Chinese home fans booed at the players and visiting fans as they watched Japan rout China 3-1. After the match, some Chinese fans rioted outside the Beijing Worker's Stadium.

Once again, on September 6, 2008, Armenia and Turkey faced each other in a 2010 FIFA World Cup qualification match in Yerevan. In an unprecedented step, Turkish president Abdullah Gul was invited to watch the match, where the presidents of Turkey and Armenia sat together, albeit behind bullet-proof glass. However, the Turkish national anthem was almost drowned out by booing from 35,000 Armenian fans, showing there is still a lot of mistrust between the two countries. However, the gesture "between the presidents showed that they believed 'football diplomacy' had achieved the most important result." This was a first for the two countries divided by the legacy of the 20th century's first genocide.

In 2010 relations between Iran and the UAE took a turn for the worse when the Football Federation of the Islamic Republic of Iran sent a letter complaining about the misuse of the Persian Gulf name. "The move was made after the UAE misrepresented the name Persian Gulf during a match between Iran's Sepahan and the UAE's Al Ain. The Emirate television displayed various banners showing a fictitious name for the Persian Gulf during the match between Iran's Sepahan and the UAE's AI Ain. The AFC must take serious measures to deal with UAE actions of the sort," Taj added. "The UAE side must be fined for showing a fictitious name for the Persian Gulf during the live broadcast of the match.

Started in 1980, the United Nations "Register of Sports Contacts with South Africa" - a record of sports exchanges with South Africa and a list of sportsmen who have participated in sports events in South Africa - prove to be an effective instrument to discourage collaboration with apartheid sport. In the 1980s South Africa was also expelled from most 
international sports bodies. The International Olympic Committee even adopted a declaration against "apartheid in sport" on June 21,1988 , for the total isolation of apartheid sport.

\section{Conclusion:}

Concluding, Sport is well placed for the development of both national identity and national pride. Although there is evidence that national team success and hosting events can contribute it is erroneous to conclude that $\square$ to increased selfesteem and national pride. All members of a community utilize sport to construct their national identity. Similarly, it should not be assumed that all people within a community would derive pride from associating themselves with sporting success. Sport is likely to be just one of a number of factors that influence perceptions of national identity and national pride. Due to increased globalization, sport and sporting events provide a site for national identities expressed with honor and pride. Some sports are more likely to become vehicles for the development and expression of national aspirations.

Olympic Games has been an effective instrument to discourage the nations collaborating with apartheid sport, expelled South Africa from most international sports bodies in 1980, and adopted a declaration for total isolation of apartheid sport. Sports teams and events provide a community with psychic benefits, which leads community pride and in turn contributes towards a community's quality of life. It confirms Sport has the ability to develop pro-social behavior which promotes the maintenance of mental well-being and developing social interaction, social cohesion, creating sense of mutual benefits for the society.

\section{References}

1. Alegi, P. (2004) Laduma! Soccer, Politics and Society in South Africa University of KwaZulu-Natal Press , Scottsville

2. Allison, L. and Monnington, T. (2002) Sport, Prestige and International Relations. Government and Opposition 37:1, pp. 106-134.

3. Asmal, K. , Chidester, D. and Lubisi, C. (2005) Legacy of Freedom: The ANC Human Rights Tradition Jonathan Ball , Johannesburg

4. Beacom, Aaron. (2000) Sport in International Relations: A Case for Cross-disciplinary Investigation. The Sports Historian 20:2, pp. 1-23.

5. Black, D. and Nauright, J. (1998) Rugby and the South African Nation Manchester University Press, Manchester

6. Booth, D. (1998) The Race Game: Sport and Politics in South Africa Frank Cass , London

7. Broere, M. and Van der Drift, R. (1997) Football Afrika! WorldView, Oxford

8. CONCACAF Confederation of North, Central American and Caribbean Association Football

9. Darby, P. (2008) Stanley Rous's 'own goal' football politics, South Africa and the contest for the FIFA Presidency in 1974.9 , p. 2.

10. Gevisser, M. (2007) Thabo Mbeki: The Dream Deferred Jonathan Ball Publishers, Johannesburg and Cape Town

11. Grundlingh, A. , Odendaal, A. and Spies, B. (1995) Beyond the Tryline: Rugby and South African Society Ravan Press, Johannesburg

12. Keys, B. (2006) Globalizing Sport: National Rivalry and International Community in the 1930s Harvard University Press, Cambridge, MA

13. Lapchick, R. (June 1976) Apartheid Sport and South Africa's Foreign Policy: 1976. UN Centre Against Apartheid, Department of Political and Security Council Affairs

14. Limb, P. (2008). The Anti-Apartheid Movements in Australia and Aoteroa/New Zealand. The Road to Democracy in South Africa: Volume 3, International Solidarity, Part 2 pp. 907-982. UNISA Press, Pretoria - South African Democratic Education Trust

15. Mbeki, T. (December 1989). The Harare Document and the International Community. Sechaba p. 12.

16. Ndlovu, S. (2004) The ANC in Exile, 1960-1970. The Road to Democracy in South Africa, Volume 1 (1960-1970) pp. 411-478. Zebra Press , Cape Town - South African Democracy Education Trust

17. Nye, J. (2004) Soft Power: The Means to Success in World Politics Public Affairs, New York

18. Nyerere, J. 'Address delivered to the convocation of Ibadan University Nigeria Julius Nyerere Foundation, Dar es Salaam 
19. Olukoshi, A. Olusanya, G. O. and Akindele, R. A. (eds) (1990) Sports and Foreign Policy: Nigeria's Decision to Boycott the 1986 Edinburgh Commonwealth Games Revisited. The Structure and Processes of Foreign Policy Making and Implementation in Nigeria, 1960-1990 p. 466. Nigerian Institute of International Affairs, Lagos

20. Organization of African Unity (October 1989) [Harare] Declaration of the OAU Ad-hoc Committee on Southern Africa on the Question of South Africa. Sechaba pp. 2-5.

21. Pahad, A. (March 2009) Reflection on the International Scene. The Thinker pp. $42-43$.

22. South African Department of Foreign Affairs (1996) South African Foreign Policy: Discussion Document Government Printer, Pretoria

23. South African Department of Foreign Affairs. Annual Report, (2007-2008), Government Printers, Pretoria 